\title{
PENGARUH STRATEGI PEMBELAJARAN PODE (PREDICT-OBSERVE-DISCUSS-EXPLAIN) MENGGUNAKAN SIMULASI PHET TERHADAP KETERAMPILAN PROSES SAINS SISWA SMA KELAS XI
}

\author{
Mareti Wulandari $^{\text {a) }}$, Siswoyo ${ }^{\text {b) }}$, Cecep E. Rustana ${ }^{\text {c) }}$ \\ Program Studi Pendidikan Fisika, Fakultas Matematika dan Ilmu Pengetahuan Alam, Universitas Negeri \\ Jakarta, Jalan Rawamangun Muka No.1 Rawamangun, Pulogadung, Jakarta Timur 13220. \\ Email: ${ }^{\text {a) }}$ mareti.mw@gmail.com, ${ }^{\text {b) }}$ siswoyo@unj.ac.id, ${ }^{\mathrm{c})}$ ce.rustana59@gmail.com
}

\begin{abstract}
Abstrak
Penelitian ini bertujuan untuk mengetahui bagaimana pengaruh strategi pembelajaran PODE (PredictObserve-Discuss-Explain) menggunakan simulasi PhET terhadap keterampilan proses sains siswa SMA kelas XI. Metode yang digunakan dalam penelitian ini adalah eksperimen dengan pretest-posttest control group design. Teknik pengambilan sampel pada penelitian ini adalah purposive sampling. Instrumen penelitian yang digunakan berupa tes keterampilan proses sains berjumlah 20 soal pilihan ganda yang telah divalidasi. Berdasarkan hasil pengolahan data, diperoleh rata-rata nilai pretest pada kelas kontrol yaitu sebesar 33 sedangkan pada kelas eksperimen sebesar 34,7. Perolehan rata-rata nilai posttest pada kelas kontrol yaitu sebesar 57 sedangkan pada kelas eksperimen sebesar 81,5. Teknik analisis data yang dilakukan yaitu dengan menggunakan teknik statistik uji-t satu pihak untuk menguji perbedaan rata-rata perolehan nilai posttest keterampilan proses sains pada kelas kontrol dan kelas eksperimen. Hasil perhitungan diperoleh nilai thitung $=11,69$ dan nilai ttabel $=1,699(\alpha=0,05 ; \mathrm{dk}=$ 29). Hal tersebut berarti nilai thitung > ttabel sehingga hipotesis nol (H0) ditolak karena nilai thitung berada diluar daerah penerimaan $\mathrm{H} 0$. Berdasarkan hasil analisis data penelitian tersebut dapat disimpulkan bahwa terdapat pengaruh positif dalam penerapan strategi pembelajaran PODE (PredictObserve-Discuss-Explain) menggunakan simulasi PhET terhadap keterampilan proses sains siswa SMA kelas XI.
\end{abstract}

Kata-kata kunci: PODE (Predict-Observe-Discuss-Explain), Simulasi PhET, Keterampilan Proses Sains

\begin{abstract}
This research aims to determine how the effect of the PODE (Predict-Observe-Discuss-Explain) learning strategy using PhET simulation on science process skills of high school students of class XI. The method used in this research was an experiment with a pretest-posttest control group design. The sampling technique in this research was purposive sampling. The research instrument used was a science process skills test totaling 20 multiple choice questions that had been validated. Based on the results of data processing, the average value of the pretest in the control class is 33 while the experimental class is 34,67. The average score of posttest in the control class is 57 while in the experimental class is 81,5 . The data analysis technique was carried out by using the t-test statistic technique to examine the differences in the average acquisition of posttest value of science process skills in the control class and the experimental class. The calculation results obtained by the value of tcount =
\end{abstract}


11,66 and the value of ttable $=1.699(\alpha=0.05 ; \mathrm{dk}=29)$. This means the value of tcount $>$ ttable so that the null hypothesis (H0) is rejected because the value of tcount is outside the reception area H0. Based on the results of the research data analysis it can be concluded that there is a positive effect in the application of the PODE (Predict-Observe-Discuss-Explain) learning strategy using PhET simulation on science process skills of high school students of class XI.

Keywords: PODE (Predict-Observe-Discuss-Explain), PhET Simulation, Science Proses Skill.

\section{PENDAHULUAN}

Melalui hasil wawancara dengan guru yang telah dilakukan di SMAN 21 Jakarta, tergambar suatu masalah belajar yang dialami siswa dalam kegiatan pembelajaran dengan materi pokok Teori Kinetik Gas yang mencakup banyak teori. Masalah belajar yang dialami oleh siswa tersebut yaitu belum memahami beberapa materi Teori Kinetik Gas. Pernyataan tersebut diperkuat dengan hasil penelitian oleh Salpan (2017) yang menyatakan bahwa banyak siswa yang beranggapan fisika merupakan mata pelajaran yang sulit dan menjemukan karena fisika banyak memuat rumus matematis [1]. Hal ini dapat dilihat setelah guru menjelaskan materi kemudian memberikan pertanyaan ke beberapa siswa terkait contoh-contoh Teori Kinetik Gas. Siswa yang ditunjuk tidak dapat menjawab pertanyaan tersebut, mereka hanya membacakan definisinya. Masalah belajar yang dialami siswa juga muncul pada pemahaman terhadap materi. Siswa belum mampu menjelaskan proses selanjutnya.

Kondisi pembelajaran seperti di atas dapat menimbulkan permasalahan yaitu siswa kurang berminat terhadap pokok bahasan Teori Kinetik Gas. Kemudian kegiatan pembelajaran tidak dapat mendorong terjadinya peningkatan kemampuan berpikir dan motivasi belajar siswa, yang berakibat pada lemahnya pemahaman siswa terhadap materi yang telah dijelaskan. Oleh sebab itu, sumber belajar atau media yang digunakan dirasa belum cukup menjelaskan materi kepada siswa. Hasil belajar akan lebih baik apabila guru menghadirkan contoh yang konkrit yang ada dalam kehidupan sehari-hari, sehingga siswa terlibat aktif dalam kegiatan belajar untuk mencari dan membangun pengetahuannya sendiri. Atas dasar kenyataan inilah perlu adanya alternatif pemecahan masalah baik dalam pemilihan media dan strategi penggunaannya, sehingga kegiatan pembelajaran dapat berlangsung aktif, efektif, dan menyenangkan.

Proses belajar terbaik adalah dengan melibatkan para siswa untuk mempelajari materi pelajaran secara aktif. Disamping itu, guru juga lebih berperan dalam memfasilitasi para siswanya belajar. Beberapa fasilitasi tersebut seperti menugaskan melaksanakan riset, memberi mereka peluang untuk mempresentasikan hasil kajian, berdiskusi dengan kelompok, dan belajar menyimpulkan hasil diskusinya. Attard juga menyatakan bahwa belajar dengan model passive learning melalui ceramah, membaca, audio-visual, dan demonstrasi hanya mampu menghasilkan pencapaian belajar paling tinggi 30\%. Bahkan bila hanya mengandalkan audio-visual, membaca, dan ceramah, pencapaian materi pelajaran yang bisa melekat dan diingat siswa masing-masing hanya mencapai $20 \%, 10 \%$ dan bahkan 5\%. Prosentase pencapaian demikian jauh berbeda dengan model belajar aktif melalui diskusi, praktik, atau mengajarkan orang lain. Pencapaian paling rendah terdapat pada metode diskusi yakni 50\%. Sedangkan praktek dan mengajar yang lain diperoleh prosentase hasil belajar lebih tinggi, yakni $75 \%$ dan 90\%. Metode Pembelajaran terakhir dilakukan dengan menjelaskan informasi pengetahuan yang dipelajarinya pada kelompoknya dengan saling bertanya, berdialog, berdiskusi atau bahkan berdebat. Dengan demikian, pembelajaran yang menitikberatkan pada siswa atau student centerd learning saat ini sangat direkomendasikan agar siswa mampu meraih hasil belajar yang maksimal [2].

Model pembelajaran PODE (Predict-Observe-Discuss-Explain) merupakan pengembangan model pembelajaran yang pertama kali diperkenalkan oleh White dan Gunston yaitu model pembelajaran POE (Predict-Observe-Explain). Irfan dalam penelitiannya juga mengatakan bahwa model pembelajaran ini mengacu pada filsafat konstruktivisme, di mana siswa akan membangun pengetahuan di pikirannya sendiri berdasarkan pengalaman langsung yang ditemuinya pada saat pembelajaran. Selama pembelajaran dengan model ini, siswa didukung untuk membangun pengetahuan mereka sendiri melalui proses penyelidikan. Siswa bekerja dengan peralatan sederhana pada setiap pengamatan mereka baik dalam model demosrasi maupun eksperimen [3]. 
Sintaks pada model ini adalah predict, observe, discuss, dan explain. Adapun langkah-langkah keempat kegiatan tersebut dalam penerapan model PODE adalah sebagai berikut:

- Predict: pada tahap ini, meminta peserta didik untuk mengamati apa yang akan didemonstrasikan, kemudian berhipotesis (membuat prediksi) terhadap fenomena yang mereka amati/rasakan.

- Observe: pada tahap ini, siswa melakukan percobaan atau guru menunjukkan proses atau demonstrasi dan meminta peserta didik untuk mencatat apa yang terjadi.

- Discuss: pada tahap ini, siswa mendiskusikan fakta-fakta yang telah mereka amati dalam percobaan yang dilakukan.

- Explain: pada tahap ini, guru meminta peserta didik untuk memberikan penjelasan yang berkaitan dengan hasil pengamatan yang dilakukan mengenai mengapa hal tersebut dapat terjadi, serta menjelaskan perbedaan antara prediksi yang dibuatnya dengan hasil observasinya [3].

Model PODE merupakan suatu model yang efisien untuk menciptakan kegiatan eksplorasi bagi para siswa mengenai konsep ilmu pengetahuan. Model ini melibatkan siswa dalam meramalkan suatu fenomena, melakukan observasi melalui demonstrasi atau eksperimen, melakukan diskusi dalam rangka meningkatkan keterampilan sosial, dan akhirnya menjelaskan hasil demonstrasi dan ramalan mereka sebelumnya. Terdapat beberapa alasan dalam pemilihan model pembelajaran ini, yaitu: (1) siswa merasa senang untuk melaksanakannya, hal ini disebabkan dalam kegiatan belajar siswa tidak hanya terbatas mendengarkan apa yang diberikan oleh guru, namun turut berperan aktif dalam kegiatan belajar seperti melaksanakan demonstrasi terkait materi yang dibahas, (2) siswa dapat memberikan contoh dari sebuah konsep abstrak yang diberikan, yaitu kemampuan siswa akan berkembang dalam mengaitkan materi yang dibahas dengan dunia nyata, (3) penerapan model ini dapat menarik perhatian siswa untuk mengikuti pelajaran, karena pembelajaran yang dilalui siswa akan dirasa lebih menarik dan bervariasi [3].

Penerapan model pembelajara tersebut perlu didukung dengan penggunaan media pembelajaran yang tepat agar tujuan pembelajaran dapat dicapai dengan maksimal. Pada penelitian ini digunakan simulasi PhET sebagai media pembelajaran. Simulasi PhET merupakan media simulasi interaktif yang menyenangkan dan berbasis penemuan (research based) yang berupa software dan dapat digunakan untuk memperjelas konsep-konsep fisis atau fenomena yang akan diterangkan yang merupakan ciptaan dari komunitas sains PhET Project di University of Colorado, USA (PhET.colorado.edu) [4]. Pada simulasi ini mencakup simulasi untuk pembelajaran fisika, biologi, dan kimia untuk kepentingan pengajaran di kelas atau belajar individu.

Tujuan utama simulasi ini adalah untuk melatih keterlibatan siswa dalam belajar serta peningkatan pembelajaran. Simulasi PhET secara khusus dirancang untuk mendukung siswa dalam membangun pemahaman konseptual yang kuat dari fisika melalui eksplorasi dan berinteraksi dengan lingkungannya. Selain itu, simulasi PhET menekankan hubungan antara fenomena kehidupan nyata dengan ilmu yang mendasari, mendukung pendekatan interaktif dan konstruktivis, memberikan umpan balik, dan menyediakan tempat kerja kreatif [5].

Pada penelitian yang telah dilakukan oleh Khoiriyah (2015) disimpulkan bahwa penggunaan media simulasi PhET dengan model pembelajaran inkuiri terbimbing dapat meningkatkan hasil belajar siswa [6]. Efek penggunaan media simulasi PhET dalam pembelajaran fisika dapat dilihat berdasarkan temuan Prihatiningtyas (2013) yang menunjukkan bahwa implementasi simulasi PhET dan KIT sederhana untuk mengajarkan keterampilan psikomotor siswa pada pokok bahasan alat optik dapat menuntaskan hasil belajar psimotor siswa [7]. Lubis (2015) menyimpulkan bahwa hasil pembelajaran fisika dengan model pembelajaran NHT (Numbered Heads Together) menggunakan media simulasi PhET lebih baik dibandingkan dengan siswa yang menggunakan model pembelajaran konvensional [8]. Hal yang sama juga ditunjukkan oleh hasil penelitian Komyadi (2013) menunjukkan bahwa penerapan model pembelajaran inquiry training menggunakan media simulasi PhET dapat meningkatkan keterampilan proses sains (aspek psikomotor dan kognitif) [9]. Berbagai penelitian sebelumnya terkait penggunaan PhET dalam pembelajaran juga menunjukkan hasil yang baik untuk peningkatan pemahaman [10]. 
Dengan menerapkan pembelajaran yang mengedepankan eksperimen, siswa dapat membangun konsep, prinsip, teori, serta hukum berdasarkan pikirannya sendiri. Melalui pegamatan atau eksperimen tersebut dapat memberikan suatu proses yang sangat berarti bagi siswa. Siswa dapat membandingkan atara teori yang telah diperoleh berdasarkan literatur dengan fakta yang mereka temukan dalam kegiatan eksperimen atau kehidupan sehari-hari. Jika antara teori dan fakta yang ditemukan tersebut terdapat perbedaan, maka akan terjadi konflik kognitif yang dialami oleh siswa, pada saat inilah terjadi proses belajar yang dialami oleh siswa karena melalui proses berpikir siswa akan memperoleh pengetahuan yang lebih bermakna dan akan tersimpan pada memorinya dalam jangka panjang [11].

Dari kegiatan tersebut, siswa akan mengembangkan kemampuan berpikir dan menggali ideidenya dalam belajar sains selayaknya seorang ilmuan. Karena tujuan utama dalam pembelajaran sains selain untuk memahami konsep juga untuk mengembangkan keterampilan siswa. Keterampilan proses sains merupakan pengkajian sains dari segi proses, unsur utama yang berfungsi sebagai roda penggerak dari hakikat sains lainnya yaitu sains sebagai produk dan sains sebagai sikap ilmiah. Keterampilan proses sains dapat ditingkatkan dengan berbagai strategi dan model pembelajaran, misalnya melalui context based learning [12], guided discovery learning [13], problem based instruction [14], discovery learning [15], integrated instructional materials [16]. Dengan keterampilan proses, siswa dapat mempelajari sains sesuai dengan apa yang para ilmuan sains lakukan, yaitu melakukan pengamatan, klasifikasi, inferensi, merumuskan hipotesis, dan melakukan eksperimen [17].

\section{METODE PENELITIAN}

Metode penelitian yang digunakan adalah metode penelitian eksperimen. Penelitian dengan metode eksperimen adalah suatu cara untuk mencari hubungan sebab akibat (hubungan kausal) antara dua faktor yang sengaja ditimbulkan oleh peneliti dengan mengeliminasi atau mengurangi atau menyisishkan faktor-faktor lain yang bisa mengganggu [18]. Alasan digunakannya metode penelitian tersebut adalah untuk mengetahui bagaimana pengaruh strategi pembelajaran PODE (PredictObserve-Discuss-Explain) menggunakan simulasi PhET terhadap keterampilan proses sains siswa SMA kelas XI. Dalam penelitian ini, jenis data yang diambil merupakan data kuantitatif dimana data terebut diambil dari pengamatan langsung oleh peneliti mengenai pengaruh strategi pembelajaran PODE (Predict-Observe-Discuss-Explain) menggunakan simulasi PhET terhadap keterampilan proses sains siswa SMA kelas XI. Jenis intrumen data yang digunakan berupa soal keterampilan proses sains berbentuk pilihan ganda. Teknik pengambilan sampel pada penelitian ini adalah nonprobability sampling dengan tipe purposive sampling, yaitu teknik penentuan sampel dengan pertimbangan tertentu. Adapun rancangan perlakuan pada penelitian ini yaitu menggunakan PretestPosttest Control Group Design.

TABEL 1. Rancangan penelitian menggunakan Pretest-Posttest Control Group Design

\begin{tabular}{lccc}
\hline Kelompok & Pre-Test & Perlakuan & Post-Test \\
\hline Eksperimen & $\mathrm{O}_{1}$ & $\mathrm{X}_{1}$ & $\mathrm{O}_{2}$ \\
Kontrol & $\mathrm{O}_{3}$ & $\mathrm{X}_{2}$ & $\mathrm{O}_{4}$ \\
\hline
\end{tabular}

Keterangan:

$\mathrm{O}_{1}$ : Tes awal keterampilan proses sains siswa (pretest) di kelas eksperimen

$\mathrm{O}_{2}$ : Tes akhir keterampilan proses sains siswa (posttest) di kelas eksperimen

$\mathrm{O}_{3}$ : Tes awal keterampilan proses sains siswa (pretest) di kelas kontrol

$\mathrm{O}_{4}$ : Tes akhir keterampilan proses sains siswa (posttest) di kelas kontrol

$\mathrm{X}_{1}$ : Perlakuan kelas eksperimen dengan menerapkan strategi pembelajaran PODE menggunakan simulasi PhET

$\mathrm{X}_{2}$ : Perlakuan kelas kontrol dengan menerapkan strategi pembelajaran langsung [19]. 
Teknik analisis data dilakukan dengan teknik statistik, yaitu menggunakan uji normalitas dan uji homogenitas untuk menguji sampel, sedangkan untuk menguji hipotesis digunakan uji-t. Dari hasil analisis tersebut diharapkan dapat menunjukkan pengaruh penggunaan strategi pembelajaran PODE (Predict-Observe-Discuss-Explain) menggunakan simulasi PhET terhadap keterampilan proses sains siswa, kemudain dapat menjadi bahan pertimbangan terhadap perancangan strategi pembelajaran yang akan digunakan.

\section{HASIL DAN PEMBAHASAN}

Pada bagian ini akan diuraikan hasil penelitian yang berupa penelitian langsung. Dalam kegiatan penelitian ini digunakan siswa di SMAN 21 Jakarta sebagai objek penelitian. Pada pelaksanaan pembelajaran, siswa dibagi menjadi 2 kelompok kelas, yaitu 30 siswa pada kelas kontrol yang diterapkan menggunakan strategi pembelajaran konvensional, serta 30 siswa pada kelas eksperimen yang diterapakan menggunakan strategi pembelajaran PODE (Predict-Observe-Discuss-Explain) dan simulasi PhET. Dalam kegiatan ini dilakukan analisis yang bertujuan untuk mengetahui keterampilan proses sains siswa setelah dilakukan proses pembelajaran menggunakan PODE (Predict-ObserveDiscuss-Explain) dan simulasi PhET. Siswa mengituki proses pembelajaran tersebut selama 6 kali pertemuan. Berdasarkan penelitian yang telah dilakukan, diperoleh data pada TABEL 2 dibawah ini:

TABEL 2. Hasil Skor Keterampilan Proses Sains

\begin{tabular}{lcccc}
\hline \multirow{2}{*}{ Statistik } & \multicolumn{2}{c}{ Kelas Kontrol } & \multicolumn{2}{c}{ Kelas Eksperimen } \\
\cline { 2 - 5 } & Pre-Test & Post-Test & Pre-Test & Post-Test \\
\hline Banyak Siswa & 30 & 30 & 30 & 30 \\
Nilai Minimum & 20 & 40 & 20 & 70 \\
Nilai Maksimum & 45 & 70 & 60 & 95 \\
Jumlah & 990 & 1710 & 1040 & 2445 \\
Rentang & 25 & 30 & 40 & 25 \\
Rata-rata & 33 & 57 & 34,67 & 81,50 \\
Median & 30 & 60 & 30 & 80 \\
Modus & 30 & 60 & 30 & 80 \\
St Deviasi & 7,14 & 9,34 & 10,50 & 6,71 \\
Varian & 51,0 & 87,24 & 110,23 & 45,09 \\
\hline
\end{tabular}

Distribusi frekuensi skor hasil posttest keterampilan proses sains siswa pada kelas kontrol dan kelas eksperimen dapat digambarkan diagram batang di bawah ini:

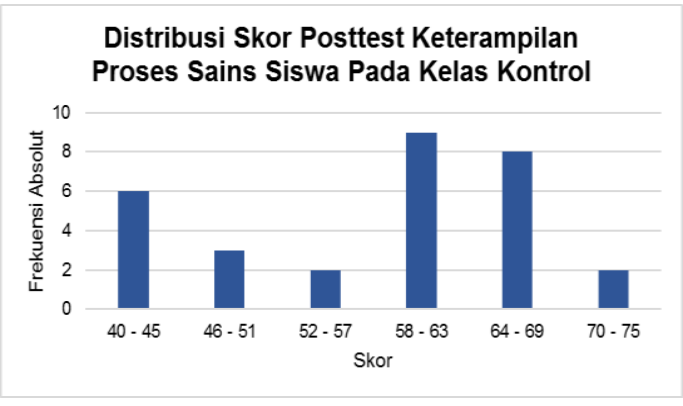

(a)

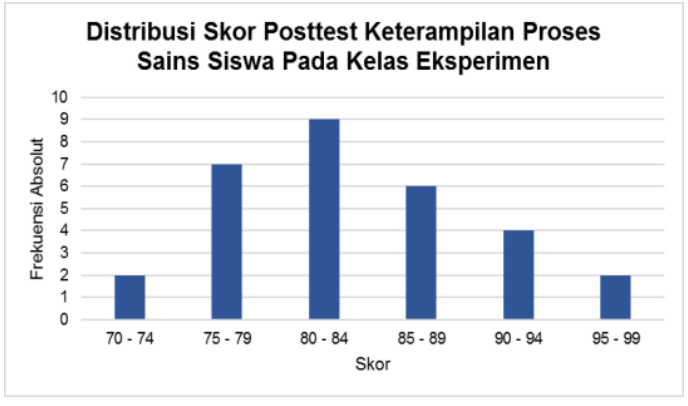

(b)

GAMBAR 1. Distribusi data skor posttest pada kelas kontrol dan kelas eksperimen

Persentase tingkat pencapaian keterampilan proses sains siswa pada kelas kontrol dan kelas eksperimen dapat digambarkan pada diagram di bawah ini: 


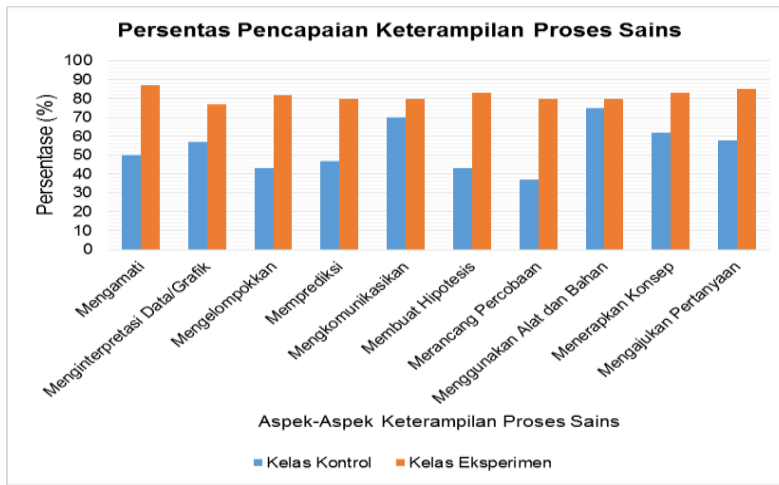

GAMBAR 2. Persentase Pencapaian Keterampilan Proses Sains Siswa

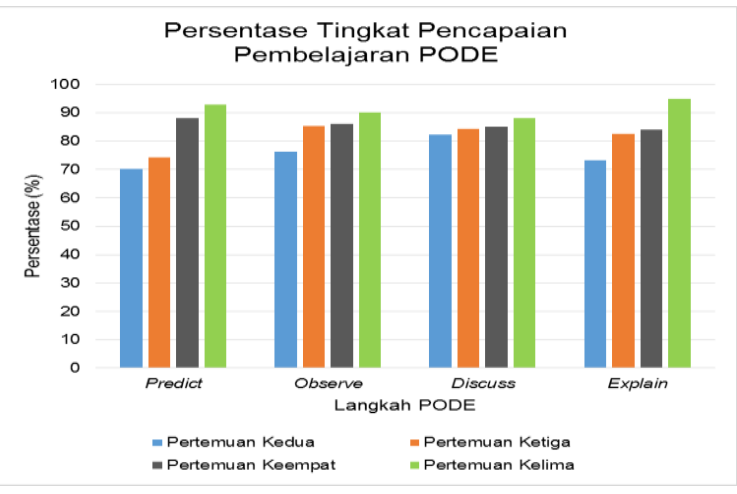

GAMBAR 3. Persentase Tingkat Pencapaian Pembelajaran PODE

Berdasarkan dari data yang telah diperoleh, data tersebut di analisis dengan uji normalitas dan uji homogenitas. Uji normalitas data padan penelitian ini menggunakan teknik Uji Liliefors dengan data yang digunakan adalah keterampilan proses sains siswa pada kelas eksperimen dan kelas kontrol. Hasil uji normalitas pada kelas eksperimen diperoleh nilai $L_{\text {hitung }}$ sebesar 0,15477 dan pada kelas kontrol sebesar 0,15220 dengan nilai $\mathrm{L}_{\text {tabel }}$ untuk jumlah responden 30 adalah 0,161 pada taraf signifikan sebesar $\dot{\alpha}=5 \%$. Berdasarkan hasil pengolahan tersebut, dapat dilihat bahwa nilai $\mathrm{L}_{\mathrm{hitung}}$ pada kedua kelas lebih rendah dibandingkan dengan nilai $\mathrm{L}_{\text {tabel}}$, sehingga dapat disimpulkan bahwa distribusi data pada nilai posttest di kedua kelas dinyataan terdistribusi normal.

Uji homogenitas ragam atau uji kesamaan variansi bertujuan untuk mengetahui sampel keterampilan proses sains siswa berasal dari populasi yang homogen atau tidak. Uji homogenitas menggunakan uji-F dengan menggunakan taraf signifikan sebesar $\alpha=5 \%$, dk pembilang $=\mathrm{n}-1=30$ $1=29$, serta $\mathrm{db}=\mathrm{k}-1=2-1=1$. Dengan menggunakan tabel Chi-Kuadrat didapat nilai $\mathrm{Xt}^{2}$ sebesar 3,841. Berdasarkan perhitungan diperoleh nilai $\mathrm{X}^{2}$ sebesar 3,103 sehingga dapat dilihat bahwa nilai $\mathrm{X}^{2}$ lebih kecil dibandingkan nilai $\mathrm{Xt}^{2}$. Maka dapat disimpulkan bahwa kedua kelompok sampel tersebut berasal dari populasi homogen.

Berdasarkan uji homogenitas data yang telah dilakukan, didapatkan bahwa kedua kelas berasal dari populasi yang homogen. Kedua kelas tersebut tersebut memiliki jumlah responden yang sama dan dikatakan kelas homogen, sehingga untuk menguji hipotesis dapat digunakan rumus uji t. Nilai uji kesamaan rata-rata dari kedua kelas dengan taraf signifikan sebesar $\alpha=5 \%$ serta derajat kebebasan $\mathrm{dk}=\mathrm{n} 1+\mathrm{n} 2-2=30+30-3=58$. Dari perhitungan menggunakan rumus uji-t diperoleh besarnya nilai thitung adalah 11,66 dan nilai dari tabel dengan taraf signifikan $\alpha=5 \%$ adalah 1,69913.

Berdasarkan penelitian yang telah dilakukan di SMAN 21 Jakarta, rata-rata perolehan hasil pretest pada kelas kontrol adalah sebesar 33 sedangkan pada kelas eksperimen sebesar 34,67. Dari data tersebut dapat dilihat bahwa kedua kelas memiliki kemampuan awal yang hampir sama karena perbedaan dari kedua kelas tersebut tidak terlalu signifikan. Setelah diberikan perlakuan yang berbeda pada kedua kelas tersebut, kelas XI MIA 3 sebagai kelas eksperimen yang diperlakukan dengan menerapkan strategi pembelajaran PODE (Predict-Observe-Discuss-Explain) mengggunakan simulasi PhET dan kelas XI MIA 2 sebagai kelas kontrol yang diperlakukan dengan menggunakan strategi pembelajaran langsung. Pada akhir kegiatan pembelajaran, kedua kelas tersebut diberikan posttest untuk mengukur kemampuan akhir keterampilan proses sains siswa. Rata-rata perolehan hasil posttest pada kelas kontrol adalah sebesar 57 sedangkan pada kelas eksperimen sebesar 81,5. 
Dilihat dari rata-rata perolehan hasil posttest pada kedua kelas tersebut, terdapat peningkatan dari rata-rata perolehan hasil pretest. Hasil Rata-rata perolehan hasil posttest pada kelas eksperimen lebih besar dibandingkan rata-rata perolehan hasil posttest pada kelas kontrol, perbedaan rata-rata hasilnya pun sangat signifikan. Setelah dilakukan pengujian hipotesis dari hasil posttest pada kedua kelas tersebut, diperoleh besarnya nilai $t_{\text {hitung }}$ adalah 11,66 dan nilai dari $t_{\text {tabel }}$ dengan taraf signifikan $\alpha=5 \%$ adalah 1,69913. Berdasarkan perhitungan tersebut, dapat dilihat bahwa nilai $t_{\text {hitung }}$ lebih besar dibandingkan dengan nilai $t_{\text {tabel}}$, sehingga dapat disimpulkan bahwa hipotesis nol $\left(\mathrm{H}_{0}\right)$ ditolak dan hipotesis alternatif $\left(\mathrm{H}_{\mathrm{a}}\right)$ diterima. Hal ini membuktikan bahwa keterampilan proses sains siswa pada kelas eksperimen yang diberikan perlakuan berupa penerapan strategi pembelajaran PODE (PredictObserve-Discuss-Explain) menggunakan simulasi PhET lebih tinggi daripada siswa pada kelas kontrol yang menerapkan strategi pembelajaran langsung. Dengan demikian strategi pembelajaran PODE (Predict-Observe-Discuss-Explain) menggunakan simulasi PhET mampu mempengaruhi keterampilan proses sains siswa kelas XI.

Persentase pencapaian keterampilan proses sains siswa kelas XI pada materi Teori Kinetik Gas di kelas eksperimen lebih tinggi dari pada pencapaian di kelas kontrol pada tiap-tiap aspek keterampilan proses sains. Pada kelas eksperimen terlihat bahwa aspek mengamati dan aspek mengajukan pertanyaan memiliki persentase tingkat pencapaian keterampilan proses sains yang paling tinggi yaitu sebesar 90\% dari 100\%, sedangkan pada kelas kontrol terlihat bahwa aspek mengajukan pertanyaan memiliki persentase tingkat pencapaian keterampilan proses sains yang paling tinggi yaitu sebesar $80 \%$ dari $100 \%$. Jika diakumulasikan, kelas eksperimen memperoleh persentase tingkat pencapaian keterampilan proses sains sebesar $81 \%$ dari $100 \%$, sedangkan kelas kontrol memperoleh persentase tingkat pencapaian keterampilan proses sains sebesar 54\% dari $100 \%$.

Pada saat dilakukan analisa kemampuan keterampilan proses sains siswa pada tiap aspeknya, hasil yang diperoleh menunjukkan bahwa kelas eksperimen lebih unggul disbanding kelas kontrol di tiap aspeknya. Aspek-aspek tersebut meliputi aspek mengamati, menginterpretasi data atau grafik, mengelompokkan, menafsirkan, mengkomunikasikan, membuat hipotesis, merancang percobaan, menggunakan alat dan bahan, menerapkan konsep, serta mengajukan pertanyaan. Saat dilakukan pengujian menggunakan uji-t, hasil perhitungannya menunjukkan bahwa strategi pembelajaran PODE (Predict-Observe-Discuss-Explain) menggunakan simulasi PhET mampu memberikan pengaruh positif terhadap seluruh aspek pada keterampilan proses sains siswa.

Pengaruh tersebut disebabkan karena dengan menerapkan strategi pembelajaran PODE (PredictObserve-Discuss-Explain) mengggunakan simulasi PhET siswa dituntut untuk mencoba sendiri simulasi yang tersedia dan mendalami perannya sebagai siswa yang aktif dalam mendapatkan informasi terkait pembelajaran. Proses pembelajaran seperti ini melibatkan siswa dalam meramalkan suatu fenomena, melakukan penyelidikan melalui demonstrasi atau eksperimen, melakukan diskusi dalam rangka meningkatkan keterampilan sosial, dan akhirnya menjelaskan hasil penyelidikan serta ramalan yang telah mereka lakukan sebelumnya, sehingga siswa mampu membangun pengetahuan di pikirannya sendiri berdasarkan pengalaman langsung yang ditemuinya pada saat pembelajaran.

Selama proses kegiatan belajar mengajar, pada kelas eksperimen teramati bahwa keadaan kelas tersebut cenderung lebih aktif dan suasana kelasnya lebih hidup karena terjadi banyak interaksi baik antar sesama siswa maupun antar guru dan siswa. Lain halnya dengan kelas kontrol, kelas ini cenderung diam dan sepi bahkan untuk menjawab pertanyaan gurupun harus dilakukan pertanyaan berulang agar siswa berani menjawab pertanyaan atau guru menunjuk salah satu siswa untuk menjawab pertanyaannya. Penelitian ini mendukung penelitian Wesley Baker (2013) yang mengungkapkan bahwa dalam pembelajaran tradisional yang memimpin kelas adalah guru, siswa sebagai objek belajar, gaya belajar mengikuti petunjuk guru, siswa seperti mengikuti kegiatan latihan [2]. Pada strategi pembelajaran PODE (Predict-Observe-Discuss-Explain) mengggunakan simulasi PhET siswa dijadikan sebagai subjek dan objek pembelajaran, gaya belajar ditentukan berdasarkan karakter siswa, serta penggunaan metode pembelajaran berbasis penemuan dan diskusi, serta siswa menerima saran dan motivasi dari guru untik menyelesaikan masalah yang terjadi. Hal tersebut dapat diartikan bahwa strategi pembelajaran PODE (Predict-Observe-Discuss-Explain) mengggunakan simulasi PhET mengutamakan proses pembelajaran untuk memperoleh pengetahuan daripada strategi pembelajaran biasa yang hanya menganggap siswa sebagai objek pembelajaran. 
Tingkat pencapaian pembelajaran menggunakan strategi pembelajaran PODE (Predict-ObserveDiscuss-Explain) pada tiap pertemuannya pun cenderung mengalami kenaikan yang signifikan. Terlihat bahwa pada tahap diskusi memiliki nilai yang paling unggul dibandingkan tahapan yang lainnya. Hal tersebut terjadi karena pada saat proses pembelajaran siswa cenderung aktif dalam berdiskusi dan berinteraksi dengan kelompoknya. Dengan tahapan-tahapan PODE (Predict-ObserveDiscuss-Explain) yang diterapkan dalam pembelajaran di kelas eksperimen, siswa dengan mudah mengaitkan pengetahuan dengan konteks kehidupan nyata, menemukan makna konsep fisika yang dipelajari berdasarkan temuannya sendiri, sehingga siswa mampu memecahkan berbagai masalah yang disajikan dalam bentuk latihan soal secara mandiri. Pembelajaran yang aktif seperti ini tentu akan meningkatkan kemampuan kognitif siswa yang menjadikan meningkatnya pula keterampilan proses sains siswa. Hal tersebut diperkuat oleh pedapat dari Ozturk yang mengatakan bahwa akan terjadi konfilik kognitif yang dialami oleh siswa jika terjadi ketidak sesuaian antara teori dan fakta yang ditemukan siswa saat bereksperimen. Pada saat itu, siswa akan mengalami proses belajar karena melalui proses berpikir siswa akan memperoleh pengetahuan yang lebih lama tersimpan dalam memori jangka panjang. Hal ini disebabkan karena pengalaman merupakan suatu informasi yang didapatkan secara empirik (penglihatan, pendengaran, penciuman, rasa dan perabaan) yang akan menjadi pengetahuan siswa [10].

\section{SIMPULAN}

Berdasarkan penelitian yang telah dilakukan, diperoleh hasil yang dapat disimpulkan bahwa strategi pembelajaran PODE (Predict-Observe-Discuss-Explain) mengggunakan simulasi PhET berpengaruh positif terhadap keterampilan proses sains siswa SMA kelas XI. Hal tersebut terlihat pada peningkatan hasil posttest pada kedua kelas, keterampilan proses sains siswa pada kelas eksperimen yang diterapkan strategi pembelajaran PODE (Predict-Observe-Discuss-Explain) mengggunakan simulasi PhET menunjukkan peningkatan yang lebih tinggi dibandingkan pada kelas kontrol. Perbandingan selisih hasil posttest pada kedua kelas tersebut diuji dengan uji-t yang diperoleh thitung lebih besar daripada $t_{\text {tabel }}$ sehingga hasil uji-t menolak $\mathrm{H}_{0}$ dan menerima $\mathrm{H}_{\mathrm{a}}$.

\section{UCAPAN TERIMAKASIH}

Terima kasih kepada Kepala Sekolah dan Guru Fisika SMAN 21 Jakarta yang telah memberikan izin untuk dijadikan sebagai tempat penelitian dan membatu selama pelaksanaan penelitian.

\section{REFERENSI}

[1] Salpan, "Peningkatan Prestasi Belajar dan Keaktifan Siswa Kelas XI MIPA 3 SMA Negeri 3 Cilacap Melalui Model Discovery Learning Berbantuan Media Inovatif dan Software Pesona Fisika Materi Teori Kinetik Gas Tahun 2015/2016," in Jurnal Penelitian dan Pengembangan Pendidikan Fisika, Vol. 3, No. 1, 2017.

[2] A. Attard, "Student Centered Learning, Toolkit for Students Staffs, and Higher Education Institution," Retrieved from Education: htpps://www.uinjkt.ac.id/id/student-centeredlearning-2/, 2010.

[3] M. Irfan, "Penerapan Model Pembelajaran Predict-Observe-Discuss-Explain untuk Meningkatkan Keterampilan Proses Sains Siswa Kelas V SD Unggulan BTN Pemda Kota Makassar," Jurnal Publikasi Pendidikan, Vol. 8, No. 1, 2018, p. 6.

[4] P. Sinulingga, T. J. Hartanto, and B. Santoso, "Implementasi Pembelajaran Fisika Berbantuan Media Simulasi PhET untuk Meningkatkan Hasil Belajar Siswa pada Materi Listrik Dinamis," Jurnal Penelitian dan Pengembangan Pendidikan Fisika, Vol. 2, No. 1, 2016, pp. 57-64. 
[5] K. Perkins, "PhET: Interactive Simulations for Teaching and Learning Physics," The Physics Teacher, Vol. 4, 2006.

[6] I. Khoiriyah, "Perbandingan Hasil Belajar Menggunakan PhET Simulation dan Kit Optika Melalui Inkuiri Terbimbing. Jurnal Pendidikan Fisika,” Vol. 3, No. 5, 2015.

[7] S. Prihatiningtyas, "Implementasi Simulasi PhET dan Kit Sederhana untuk Mengajarkan Keterampilan Psikomotor Siswa Pada Pokok Bahasan Alat Optik," Jurnal Pendidikan IPA Indonesia, Vol. 2, No. 1, 2013, p. 1.

[8] F. M. Lubis, "Efek Model Pembelajaran Kooperatif Tipe NHT (Numbered Heads Together) Menggunakan Media Simulasi PhET," Jurnal Tabularasa PPS UNIMED, Vol. 12, No. 1, 2015, p. 1.

[9] Komyadi, Penerapan Media Simulasi PhET Untuk Meningkatkan Aktivitas Belajar Siswa Pada Fase Pengumpulan Data Percobaan dan Mengolah Serta Merumuskan Suatu Penjelasan Dalam Model Pembelajaran Inquiry Training di SMA 5 Takengon, Medan: FMIPA, Universitas Negeri Medan, 2014.

[10] S. Siswoyo, "Pemahaman Mahasiswa Tentang Efek Fotolistrik", jpppf, vol. 1, no. 1, pp. 77 - 84, Jun. 2015.

[11] M. E. Ozturk, "The Effect of Think-Explain-Apply Teaching Method on The Success of Learning-Teaching: A Laboratory Study," International Journal of Environmental \& Science Education, 2008, p. 4.

[12] A. Malik, E. Kurnia Y, and S. Robiatus S, "Peningkatan Keterampilan Proses Sains Siswa melalui Context Based Learning”, jpppf, vol. 2, no. 1, pp. 23 - 30, Jun. 2016.

[13] I. M. Astra and R. S. Wahidah, "Peningkatan Keterampilan Proses Sains Siswa Melalui Model Guided Discovery Learning Kelas XI MIPA pada Materi Suhu dan Kalor", jpppf, vol. 3, no. 2, pp. 181 - 190, Dec. 2017.

[14] A. Malik, "Model Pembelajaran Problem Based Instruction untuk Meningkatkan Penguasaan Konsep dan Keterampilan Proses Sains Mahasiswa", jpppf, vol. 1, no. 1, pp. 9 16, Jun. 2015.

[15] M. Yusuf and A. R. Wulan, "Penerapan Model Pembelajaran Discovery Learning Menggunakan Pembelajaran Tipe Shared dan Webbed untuk Meningkatkan Keterampilan Proses Sains”, jpppf, vol. 1, no. 2, pp. 19 - 26, Dec. 2015.

[16] D. Desnita and D. Susanti, "Science Process Skills-Based Integrated Instructional Materials to Improve Student Competence Physics Education Prepares Learning Plans on Teaching Skills Lectures”, jpppf, vol. 3, no. 1, pp. 35 - 42, Jun. 2017.

[17] E. Y. Widayanti, "Penguasaan Keterampilan Proses Sains Dasar Siswa Mdrasah Ibtidaiyah (Studi Pada Madrasah Mitra STAIN Ponorogo)," Kodifikasi, Vol. 9, No. 1, 2015.

[18] S. Arikunto, Prosedur Penelitian Suatu Pendekatam Praktek. Jakarta: PT RINEKA CIPTA, 2002.

[19] Sugiyono, Metode Penelitian Pendekatan Kuantitatif, Kualitatif dan R\&D. Bandung: Alfabeta, 2017. 
